\title{
PENERAPAN MODEL PEMBELAJARAN KONTEKSTUAL UNTUK MENINGKATKAN AKTIVITAS DAN HASIL BELAJAR UKUR TANAH SISWA SMK NEGERI 1 LUBUK PAKAM
}

\author{
Raden Ginting ${ }^{1}$, Juanda Sianipar ${ }^{2}$ \\ ${ }^{1}$ Alumni Program Studi Teknik Bangunan, Fakultas Teknik UNIMED \\ ${ }^{1}$ Dosen Pengajar Jurusan Pendidikan Teknik Bangunan, Fakultas Teknik UNIMED \\ (sianiparjuanda@gmail.com)
}

\begin{abstract}
ABSTRAK
Penelitian ini bertujuan untuk mengetahui peningkatan aktivitas dan hasil belajar Ukur Tanah siswa kelas X program keahlian Teknik Gambar Bangunan SMK Negeri 1 Lubuk Pakam yang dilakukan pada semester ganjil tahun pelajaran 2014/2015 melalui model pembelajaran Kontekstual dengan jumlah siswa 32 orang. Dalam penelitian ini dilakukan dalam dua siklus pada siklus I terdiri dari dua kali pertemuan dan siklus II terdiri dari dua kali pertemuan. Setiap siklus terdiri dari tahap perencanaan (planning), pelaksanaan (acting), pengamatan (observating), dan refleksi (reflecting). Teknik pengumpulan data dengan observasi dan tes hasil belajar.

Dari hasil uji coba instrumen yang terdiri dari 20 soal pada siklus I, hanya 15 soal yang dapat digunakan dengan keterangan 16 soal yang valid, indeks kesukaran soal diperoleh 9 kategori sedang dan 11 kategori mudah, daya beda soal diperoleh 1 soal sangat baik, 5 soal baik, 9 soal cukup, 5 soal jelek dan uji reliabilitas 0, 65 (tinggi). Sedangkan untuk 20 soal di siklus II, hanya 14 soal yang dapat digunakan dengan keterangan 15 soal valid, indeks kesukaran diperoleh 9 kategori sedang dan 11 kategori mudah, daya beda soal diperoleh 5 soal baik, 12 soal cukup, 3 soal jelek, uji reliabilitas 0,67(tinggi). Berdasarkan hasil observasi dan evaluasi pada setiap pembelajaran ditemukan peningkatan dari siklus I ke siklus II. Untuk aktivitas belajar dengan penilaian kategori Kurang Aktif dari 0 orang menjadi 0, kategori Cukup Aktif dari 14 orang menjadi 0 orang, kategori Aktif dari 10 orang menjadi 2 orang dan kategori Sangat Aktif dari 8 menjadi 30 orang. Untuk hasil belajar dengan kategori Tidak Kompeten dari 15 orang menjadi 0, kategori Cukup Kompeten dari 9 orang menjadi 7 orang, kategori Kompeten dari 8 orang menjadi 15 orang dan kategori Sangat Kompeten dari 0 menjadi 10 orang. Hasil penelitian menunjukkan bahwa penerapan model pembelajaran Kontekstual dapat meningkatkan aktivitas belajar siswa, dan meningkatkan hasil belajar siswa pada mata pelajaran Ukur Tanah.
\end{abstract}

Kata Kunci : Model Pembelajaran Kontekstual, Aktivitas, Hasil Belajar, Ukur Tanah

\begin{abstract}
This study aims to determine the increase in activity and learning outcomes Measure Soil class X Architecture Engineering skills program SMK 1 Lubukpakam performed on odd semester of academic year 2014/2015 through contextual learning model with the number of students 32 people. In this study conducted in two cycles in the first cycle consists of two meetings and the second cycle consists of two meetings. Each cycle consists of the planning stage (planning), implementation (acting), observations (observating) and reflection (reflecting). The technique of collecting data through observation and tests of learning outcomes.From the test results of the instrument consists of 20 questions on the first cycle, only 15 questions that can be used with the information 16 about valid, the index difficulty matter obtained 9 medium category and 11 categories easily, the power
\end{abstract}




\section{Penerapan Model Pembelajaran Kontekstual untuk Meningkatkan Aktivitas dan Hasil Belajar Ukur Tanah Siswa SMK Negeri 1 Lubuk Pakam}

difference matter obtained one question very well, 5 questions well, enough about the 9, 5 about the ugly and test reliability 0, 65 (high). As for the 20 questions in the second cycle, only 14 questions that can be used with information 15 about valid, the index difficulty gained 9 medium category and 11 categories easily, the power difference matter obtained 5 about the good, 12 about enough, 3 about the ugly, reliability testing 0,67 (high).Based on observation and evaluation at each study found an increase from the first cycle to the second cycle. Assessment for learning activities with less active category of 0 people become 0, Active Enough categories from 14 to 0 people, Active category of 10 to 2 people and categories of Highly Active from 8 to 30. For learning outcomes by category Not Competent from 15 to 0, the Competent Enough categories from 9 to 7 people, the Competent category from 8 to 15 persons and the category of Highly Competent from 0 to 10 men. The results showed that the application of contextual learning model can improve students' learning activities, and improving student learning outcomes in subjects Measure Land.

Keywords : Contextual Learning Model, Activity, Learning Outcomes, Measure Soil

\section{Pendahuluan}

Pendidikan adalah usaha untuk mengembangkan potensi Sumber Daya Manusia (SDM) melalui kegiatan pembelajaran dan pendidikan merupakan proses pembentukan kemampuan dasar yang fundamental, baik yang menyangkut daya pikir maupun daya emosional yang diarahkan kepada tabiat manusia dan kepada sesamanya. Tujuan pendidikan nasional dirumuskan dalam UU No. 20 Tahun 2003 Pasal 3, yang menyatakan bahwa pendidikan nasional berfungsi mengembangkan kemampuan dan membentuk watak serta peradaban bangsa yang bermartabat dalam rangka mencerdaskan kehidupan bangsa, bertujuan untuk mengembangkan potensi peserta didik agar menjadi manusia yang beriman dan bertakwa kepada Tuhan Yang Maha Esa, berakhlak mulia, sehat, berilmu, cakap, kreatif, mandiri, dan menjadi warga Negara yang demokratis serta bertanggung jawab.

Pendidikan di Indonesia terbagi dalam tiga jalur utama, yaitu pendidikan formal, nonformal dan informal. Pendidikan formal adalah kegiatan yang sistematis, bertingkat/berjenjang, dimulai dari sekolah dasar sampai dengan perguruan tinggi dan yang setaraf dengannya; termasuk kedalamnya ialah kegiatan studi yang berorientasi akademis dan umum, program spesialisasi, dan latihan professional, yang dilaksanakan dalam waktu yang terus menerus. Pendidikan informal adalah proses yang berlangsung sepanjang usia sehingga sehingga setiap orang memperoleh nilai, sikap, keterampilan, dan pengetahuan yang bersumber dari pengalaman hidup seharihari, pengaruh lingkungan termasuk di dalamnya adalah pengaruh kehidupan keluarga, hubungan dengan tetangga, lingkungan pekerjaan dan permainan, pasar, perpustakaan, dan media massa. Pendidikan nonformal ialah setiap kegiatan teroganisasi dan sistematis, di luar sistem persekolahan yang , dilakukan secara mandiri atau merupakan bagian penting dari kegiatan yang lebih luas, yang sengaja dilakukan untuk melayani peserta didik tertentu di dalam mancapai tujuan belajarnya.

Salah satu pendidikan formal adalah Sekolah Menengah Kejuruan (SMK). SMK sebagai lembaga memiliki bidang keahlian yang berbeda-beda menyesuaikan dengan lapangan kerja yang ada. Di SMK para siswa dididik dan dilatih keterampilan agar profesional dalam bidang keahliannya masingmasing. Sesuai dengan perkembangan pendidikan di Indonesaia, standar lulusan kurikulum 2013 telah diatur melalui Permendikbud Nomor 54 Tahun 2013 tentang Standar Kompetensi Lulusan Pendidikan Dasar dan Menengah yang dirumuskan sebagai berikut : 1). Kemampuan lulusan dalam dimensi sikap; manusia yang memiliki pribadi yang beriman, berakhlak mulia, percaya diri, dan bertanggung jawab dalam berinteraksi secara efektif dengan lingkugan sosial, alam sekitar, serta dunia dan peradabannya. Pencapaian pribadi tersebut dilakukan melalui proses : menerima, menjalankan, menghargai, menghayati, dan mengamalkan. 


\section{Raden Ginting - Juanda Sianipar}

Kemampuan lulusan dalam dimensi keterampilan; manusia yang memiliki pribadi yang berkemampuan piker dan tindak yang efektif dan kreatif dalam ranah abstrak dan konkret. Pencapain tersebut dilakukan melalui proses: mengamati, menanya, mencoba, mengolah, menyaji, menalar, dan mencipta. 3) Kemampuan lulusan dalam dimensi pengetahuan; manusia yang memiliki pribadi yang menguasai ilmu pengetahuan, teknologi, seni, budaya dan berwawasan kemanusiaan, kebangsaan, kenegaraan, dan peradaban. Pencapaian pribadi tersebut dilakukan melalui proses: mengetahui, memahami, menerapkan, menganalisa, dan mengevaluasi.

Lulusan dari SMK seharusnya telah siap untuk bekerja setelah dibekali di bangku sekolah. Dunia kerja menuntut kemampuan dan keterampilan lulusan SMK di bidangnya masing-masing agar dapat dikembangkan pada pekerjaan yang akan mereka dapatkan. Dunia kerja yang bergerak di bidang konstruksi membutuhkan lulusan SMK jurusan Bangunan, yang diantaranya terdapat jurusan Gambar Bangunan, Konstruksi Batu dan Beton, Konstruksi Kayu dan sebagainya. Salah satu mata pelajaran yang dibutuhkan dalam bidang konstruksi ini adalah Ukur Tanah. Mata Pelajaran Ukur Tanah pada dasarnya dimaksudkan untuk mendidik dan melatih siswa agar dapat berkompeten dibidang survey dan pemetaan, sehingga siswa nantinya dapat mengaplikasikan kedalam dunia kerja. SMK Negeri 1 Lubuk Pakam merupakan salah satu SMK yang memiliki program keahlian Teknik Gambar Bangunan yang melaksanakan serangkaian kegiatan yang meliputi mata pelajaran keteknikan dan Ukur Tanah adalah salah satu mata pelajaran program produktif yang diterima siswa di sekolah tersebut.

Tabel 1. Data Hasil Belajar Ukur Tanah di SMK Negeri I Lubuk Pakam Kelas X TGB A Tahun Ajaran 2013/2014

\begin{tabular}{|c|c|c|c|c|}
\hline TA & Nilai & $\begin{array}{l}\text { Abs } \\
\text { olute }\end{array}$ & Persentase & Ket \\
\hline \multirow{4}{*}{$2012 / 2013$} & $\begin{array}{l}90- \\
100\end{array}$ & - & - & $\begin{array}{c}\text { Sangat } \\
\text { Kompeten }\end{array}$ \\
\hline & $80-89$ & 4 & 12,5 & Kompeten \\
\hline & $70-79$ & 19 & 59,37 & Cukup \\
\hline & $<70$ & 9 & 28,12 & $\begin{array}{l}\text { Kompeten } \\
\text { Tidak } \\
\text { Kompeten }\end{array}$ \\
\hline
\end{tabular}

(sumber: SMK Negeri 1 Lubuk Pakam)
Dari persentase hasil belajar siswa di atas, dapat dilihat bahwa siswa yang Tidak Kompeten 28,12\%, siswa yang Cukup Kompeten 59,37\%, siswa yang Kompeten $12,50 \%$, sedangkan siswa yang Sangat Kompeten belum ada. Dari data tersebut dapat kita ketahui bahwa nilai yang dicapai belum optimal, dan perlu mendapat perbaikan. Dari hasil observasi dan wawancara yang dilakukan penulis pada tanggal 16 dan 18 Oktober 2013, metode yang digunakan selama ini adalah ceramah, pemberian tugas dan diskusi kelompok. Melalui metode yang diterapkan selama ini, siswa cenderung pasif dan kurang tertarik dalam mengikuti pembelajaran, sehingga nilai yang dicapai belum optimal. Padahal dengan mendapatkan nilai yang tinggi pada mata pelajaran ini akan sangat membantu para siswa agar siap untuk bekerja setelah lulus nantinya.

Melalui model pembelajaran kontekstual (contextual teaching and learning) yang menekankan keterkaitan setiap materi atau topik pembelajaran dengan kehidupan nyata, diharapkan pembelajaran akan lebih mudah diserap siswa. Dengan demikian, pembelajaran selain akan lebih menarik, juga akan dirasakan sangat dibutuhkan oleh setiap siswa karena apa yang dipelajari dirasakan langsung manfaatnya. Sehingga aktivitas dan hasil belajar siswa akan meningkat.

Aktivitas merupakan prinsip atau asas yang sangat penting di dalam interaksi belajarmengajar. Tanpa aktivitas kegiatan belajar mengajar tidak mungkin dapat berlangung dengan baik. Sardiman (2004: 99) mengatakan bahwa aktivitas belajar merupakan serangkaian kegiatan yang meliputi keaktifan siswa dalam mengikuti pelajaran, bertanya, mencatat, mendengar, berpikir, membaca dan segala kegiatan yang dilakukan yang dapat menunjang prestasi belajar.

Selanjutnya Sriyono (2004: 81) mengatakan bahwa: "Aktivitas adalah segala kegiatan yang dilaksanakan dengan baik secara jasmani atau rohani. Aktivitas siswa selama proses belajar mengajar merupakan salah satu indikator adanya keinginan siswa untuk belajar. Aktivitas siswa merupakan kegiatan atau perilaku yang terjadi selama proses belajar mengajar. Kegiatan-kegiatan yang dimaksud adalah kegiatan yang mengarah pada proses belajar seperti bertanya, mengajukan pendapat, mengerjakan tugas-tugas, dapat menjawab 


\section{Penerapan Model Pembelajaran Kontekstual untuk Meningkatkan Aktivitas dan Hasil Belajar Ukur Tanah Siswa SMK Negeri 1 Lubuk Pakam}

pertanyaan guru dan bisa bekerjasama dengan siswa lain, serta tanggung jawab terhadap tugas yang diberikan".

Menurut Sanjaya (2006:132) bahwa "aktivitas tidak dimaksudkan terbatas pada aktivitas fisik, tetapi juga meliputi aktivitas yang bersifat psikis seperti aktivitas mental".

Adapun jenis-jenis aktivitas dalam belajar yang digolongkan oleh Paul B. Diedric (Sardiman, 2011:101) adalah sebagai berikut:

a. Visual Activities. Misalnya membaca, memperhatikan gambar demonstrasi, percobaan, mengamati pekerjaan orang lain dan sebagainya.

b. Oral Activities. Misalnya menyatakan, merumuskan, bertanya, memberi saran, berpendapat, diskusi interupsi dan sebagainya.

c. Listening Activities. Misalnya mendengarkan uraian, percakapan, diskusi, musik, pidato dan sebagainya.

d. Writing Activities. Misalnya menulis cerita, karangan, laporan, menyalin dan sebagainya.

e. Drawing Activities. Misalnya menggambar, membuat grafik, peta, diagram dan sebagainya.

f. Motor Activities. Misalnya melakukan percobaan, membuat konstruksi, model, mereprasi, berkebun, beternak dan sebagainya.

g. Mental Activities. Misalnya menanggapi, mengingat, memecahkan soal, menganalisis, mengambil kesimpulan dan sebagainya.

h. Emotinal Activities. Misalnya merasa gugup, berani, bosan, melamun, tenang dan sebagainya.

Dari uraian di atas dapat diambil pengertian aktivitas belajar adalah keaktifan siswa baik jasmani atau rohani dalam bentuk sikap, pikiran, mental, perhatian dalam kegiatan belajar guna menunjang keberhasilan proses belajar mengajar dan memperoleh manfaat dari kegiatan tersebut.

Menurut Hamalik (2009:30) "hasil belajar adalah terjadinya perubahan tingkah laku pada diri siswa, yang dapat diamati dalam bentuk perubahan pengetahuan, sikap, dan ketrampilan". Perubahan tersebut diartikan adanya peningkatan dan pengembangan yang lebih baik dibanding sebelumnya. Perubahan yang timbul pada siswa harus mengarah pada perubahan positif yang berupa kecakapan sikap, kebiasaan dan pengertian.
Menurut Yasa (2008: diakses tanggal 5 Desember 2013) "Hasil belajar dapat diartikan sebagai hasil yang dicapai siswa setelah mengalami proses pembelajaran dalam jangka waktu tertentu". Menyimpulkan bahwa "hasil belajar adalah kemampuan-kemampuan yang dimiliki siswa setelah ia menerima pengalaman belajarnya".

Menurut Bloom (dalam Sardiman, 2009:23), ada tiga kemampuan yang diharapkan siswa sebagai hasil belajar yaitu :

a. Kognitif Domain, yaitu perilaku yang berhubungan dengan pengetahuan, ingatan, pemahaman, menjelaskan, menguraikan, merencanakan, menilai, dan menerapkan.

b. Affective Domain, yaitu perilaku yang berhubungan dengan sikap menerima, memberikan respons, menilai, organisasi dan karakteristik.

c. Psycomotor Domain, yaitu perilaku yang berhubungan dengan ketrampilan atau skill yang berkaitan dengan fisik.

Dari pendapat di atas, maka dapat diambil kesimpulan bahwa hasil belajar adalah segala perubahan tingkah laku (didasari pengetahuan dan keterampilan) ke arah lebih baik yang terjadi pada individu atau kelompok setelah mengalami proses belajar.

Pembelajaran kontekstual (contextual teaching and learning) merupakan konsep belajar yang dapat membantu guru mengaitkan antara materi yang diajarkan dengan situasi dunia nyata siswa dan mendorong siswa membuat hubungan antara pengetahuan yang dimilikinya dengan penerapan dalam kehidupan mereka sebagai anggota keluarga dan masyarakat (Nurhadi,2002).

Untuk memperkuat dimilikinya pengalaman belajar yang aplikatif bagi siswa, tentu saja diperlukan pembelajaran yang lebih banyak memberikan kesempatan kepada siswa untuk melakukan, mencoba, dan mengalami sendiri (learning to do), dan bahkan sekedar pendengar yang pasif sebagaimana penerima terhadap semua informasi yang disampaikan guru. Oleh sebab itu, melalui pembelajaran kontekstual, mengajar bukan transformasi pengetahuan dari guru kepada siswa dengan menghafal sejumlah konsep-konsep yang sepertinya terlepas dari kehidupan nyata, akan tetapi lebih ditekankan pada upaya memfasilitasi siswa untuk mencari kemampuan untuk bisa hidup (life skill) dari apa yang dipelajarinya. Dengan demikian, pembelajaran 


\section{Raden Ginting - Juanda Sianipar}

akan lebih bermakna, sekolah lebih dekat dengan lingkungan masyarakat (bukan dekat dari segi fisik), akan tetapi secara fungsional apa yang dipelajari di sekolah senantiasa bersentuhan dengan situasi dan permasalahan kehidupan yang terjadi di lingkungannya (keluarga, masyarakat).

Pembelajaran kontekstual merupakan suatu konsep belajar dimana guru menghadirkan situasi dunia nyata kedalam kelas dan mendorong siswa membuat hubungan antara pengetahuan yang dimilikinya dengan penerapan dalam kehidupan mereka sebagai anggota kelurga dan masyarakat (Nurhadi, 2003:4). Selain itu, Pembelajaran kontekstual adalah konsep belajar yang membantu guru mengaitkan antara materi yang diajarkannya dengan situasi dunia nyata siswa dan mendorong siswa membuat hubungan antara pengetahuan yang dimilikinya dengan penerapannya dalam kehidupan mereka sehari-hari, dengan melibatkan tujuh komponen utama pembelajaran kontekstual, yakni: kontruktivisme, bertanya, inkuiri, masyarakat belajar, pemodelan dan penilaian autentik (Trianto, 2008:20).Selain itu, Sanjaya (2006:2250) menyatakan bahwa pembelajaran kontekstual (Contextual Teaching and Learning) adalah suatu strategi pembelajaran yang menekankan kepada proses keterlibatan secara penuh untuk dapat menemukan materi yang dipelajari dan menghubungkannya dengan situasi kehidupan nyata sehingga mendorong siswa untuk dapat menerapkannya dalam kehidupan mereka.

Dari pendapat-pendapat di atas maka dapat ditarik kesimpulan bahwa pembelajaran kontekstual merupakan suatu konsep belajar yang menuntut guru untuk mengaitkan antara materi pembelajaran dengan situasi dunia nyata siswa, dan mendorong siswa untuk terlibat secara penuh pada materi yang dipelajarinya dan dapat menerapkannya dalam kehidupan mereka

\section{Metodologi Penelitian}

Penelitian ini dilaksanakan di SMK Negeri 1 Lubuk Pakam yang beralamat di jalan Galang pada semester ganjil tahun ajaran 2014/2015, pada tanggal 13 Setember sampai 29 September 2014.

Dalam penelitian ini yang menjadi subjek penelitian adalah siswa kelas $X$ Program Keahlian Teknik Gambar Bangunan Tahun
Pelajaran 2013/2014, yaitu sebanyak 1 kelas yang terdiri dari 32 orang.

Menurut Rusman (2012:192) sebelum melaksanakan pembelajaran model kontekstual, terlebih dahulu guru harus membuat desain (skenario) pembelajarannya, sebagai pedoman umum dan sekaligus sebagai alat kontrol dalam pelaksanaannya. Pengembangan setiap komponen pembelajaran kontekstual dapat dilakukan melalui langkahlangkah sebagai berikut:

a. Mengembangkan pemikiran siswa untuk melakukan kegiatan belajar lebih bermakna, apakah dengan cara bekerja sendiri, menemukan sendiri, dan mengonstruksi sendiri pengetahuan dan keterampilan baru yang akan dimilikinya.

b. Melaksanakan kegiatan inquiri untuk semua topik yang diajarkan.

c. Mengembangkan sifat ingin tahu siswa melalui memunculkan pertanyaanpertanyaan.

d. Menciptakan masyarakat belajar, seperti melalui kegiatan kelompok berdiskusi, tanya jawab, dan lain sebagainya.

e. Menghadirkan model sebagai contoh pembelajaran, bisa melalui ilustrasi, model, bahkan media yang sebenarnya.

f. Membiasakan anak untuk melakukan refleksi dari setiap kegiatan pembelajaran yang telah dilakukan.

g. Melakukan penilaian secara objektif, yaitu melalui kemampuan yang sebenarnya pada setiap siswa.

Prosedur penelitan merupakan tahapantahapan yang dilakukan dalam proses penelitian. Prosedur yang akan dilakukan adalah sebagai berikut:

\subsection{Siklus I}

\subsubsection{Perencanaan}

Maka perencanaan yang akan dilakukan di siklus I adalah sebagai berikut:

a. Melakukan analisis kurikulum untuk mengetahui kompetensi dasar yang akan disampaikan kepada siswa dengan menggunakan model pembelajaran Kontekstual

b. Membuat rencana pembelajaran Kontekstual

c. Membuat lembar kerja siswa

d. Membuat instrumen yang digunakan dalam siklus PTK

e. Menyususn alat evaluasi pembelajaran 


\section{Penerapan Model Pembelajaran Kontekstual untuk Meningkatkan Aktivitas dan Hasil Belajar Ukur Tanah Siswa SMK Negeri 1 Lubuk Pakam}

\subsubsection{Pelaksanaan Tindakan}

Dalam setiap siklus dilaksanakan dengan durasi waktu 4 × 45 menit. Pada siklus pertama, pertemuan ini diawali dengan sub materi deskripsi ukur tanah. Pembelajaran dilakukan dalam tiga tahap, yaitu tahap pendahuluan, tahap inti dan tahap penutup. Pada tahap pendahuluan guru bidang studi menjelaskan model dan tujuan pembelajaran. Tahap inti, yaitu pelaksanaan model pembelajaran Kontekstual diawali dengan memperkenalkan model pembelajaran Kontekstual kepada siswa. Kemudian peneliti membagi naskah pembelajaran kepada siswa pada sub materi deskripsi ukur tanah. Dalam hal ini, guru mengembangkan komponen pembelajaran kontekstual selama proses belajar mengajar berlangsung melalui langkah-langkah pembelajaran kontekstual. Langkah petama yaitu mengembangkan pemikiran siswa untuk melakukan kegiatan belajar lebih bermakna dengan cara bekerja sendiri, dan mengkonstruksi sendiri pengetahuan dan keterampilan baru yang akan dimiliki oleh siswa. Kemudian melaksanakan kegiatan inquiri sejauh mungkin. Selanjutnya guru akan membangkitkan rasa ingin tahu siswa dengan memunculkan pertanyaanpertanyaan terkait dengan materi pembelajaran. Langkah selanjutnya adalah menciptakan masyarakat belajar dengan cara memmbuat tanya jawab. Setelah itu, guru memberikan ilustrasi yang bertujuan menggambarkan pengukuran suatu wilayah. Selama proses tersebut di atas, peneliti dan kolaborator (guru) melakukan pengamatan terhadap aktivitas siswa sekaligus melakukan penilaian. Pada kegiatan penutup peneliti dan kolaborator melakukan refleksi dari setiap kegiatan pembelajaran yang telah dilakukan, kemudian melakukan penilaian secara objektif, memberikan tugas rumah kepada siswa dan memberikan gambaran materi yang akan dipelajari pada pertemuan selanjutnya

Pertemuan kedua diawali dengan memberikan beberapa pertanyaan tentang materi yang sudah dipalajari sebelumnya yang bertujuan untuk mengingat apa yang telah dipelajari siswa sekaligus untuk mengembangkan pemikiran siswa. Kemudian guru melanjutkan materi peajaran memasuki materi selanjutnya, yaitu ruang lingkup ilmu ukur tanah. Kemudian dilanjuktkan dengan langkah-langkah pembelajaran kontekstual seperti pada pertemuan pertama. Pada pertemuan ini, siswa terlihat lebih memahami model pembelajaran kontekstual dibandingkan dengan pertemuan pertama. Hal ini diikuti dengan sedikit perkembangan dalam hal berfikir, bekerja sendiri, memberikan tanggapan dan dalam hal bertanya.

\subsubsection{Pengamatan}

Dalam penelitian tindakan kelas, observasi dilaksanakan dengan beberapa aspek yang diamati adalah sebagai berikut:

a. Mengamati aktivitas belajar siswa dalam proses pembelajran berlangsung

b. Menganalisa hasil tes dan observasi pada pelaksanaan tindakan untuk menetapkan tingkat keberhasilan

\subsubsection{Refleksi}

Refleksi

dilakukan dengan menganalisis hasil kerja peserta didik, lembar pengamatan yang telah diisi dari hasil diskusi yang dilakukan peneliti dan pengamat. Adapun Refleksi

a. Mengkaji berbagai hal yang terjadi dan seharusnya dilakukan

b. Membuat kesimpulan sebagai dasar untuk melaksanakan siklusberikutnya

\subsection{Siklus II}

Pada prinsipnya semua kegiatan siklus II mirip dengan siklus I. Siklus II merupakan perbaikan pada siklus I, terutama didasarkan atas hasil refleksi pada siklus I.

\subsubsection{Perencanaan}

Meninjau kembali rancangan pembelajaran yang disiapkan untuk siklus 2 dengan melakukan revisi sesuai hasil refleksi 1. Adapun perencanaan nya 


\section{Raden Ginting - Juanda Sianipar}

a. Mengidentifikasi masalah yang muncul pada siklus I dan penetapan alternatif pemecahan masalah

b. Merencanakan pengembangan program yang dilakasanakan pada siklus II, untuk menyelesaikan permasalahan pada siklus I

\subsubsection{Pelaksanaan Tindakan}

Pelaksanaan tindakan yang akan dilakukan adalah sama seperti pelaksanaan pada siklus I.

\subsubsection{Pengamatan}

Guru dan peneliti melakukan pengamatan yang sama seperti pada siklus I.

\subsection{Refleksi}

Refleksi pada siklus II ini dilakukan untuk melakukan penyempurnaan pembelajaran dengan menggunakan pembelajaran Kontekstual di harapkan dapat meningkatkan Aktivitas dan hasil belajar peserta didik.

\subsection{Teknik Pengumpulan Data}

Teknik pengumpulan data dalam penelitian ini menggunakan tes dan Observasi Aktvitas . Teknik tes digunakan memperoleh data hasil belajar Ukur Tanah siswa dan Observasi digunakan untuk mengetahui Aktivitas belajar siswa.

\subsubsection{Observasi Aktivitas Siswa}

Obsevasi digunakan untuk mengumpulkan data tentang aktivitas belajar siswa dalam proses belajar mengajar dan penerapan model pembelajaran Kontekstual. Observasi yang dilakukan dalam penelitian ini dengan mengunakan lembar Observasi aktivitas siswa dalam kelompok dengan menganalisis tingkat keaktifan siswa dalam proses belajar mengajar berlangsung.

a. Aspek Aktivitas yang dinilai

1) Visual activities (Memperhatikan soal yang akan di bahas dalam diskusi)

2) Oral activities (Bertanya dan mengemukakan pendapat dan saran)
3) Drawing activities (membuat tabel)

4) Mental activities (memberi tanggapan, memecah soal,menaati peraturan).

b. Kriteria skor

$$
\begin{aligned}
& 1=\text { Tidak pernah melakukan } \\
& 2=\text { Dilakukan namun jarang }(1 \mathrm{x}-2 \mathrm{x}) \\
& 3=\text { Sering dilakukan } \\
& 4=\text { Sangat sering dilakukan }
\end{aligned}
$$

c. Kriteria Penilaian

Menurut Sudjiono ( 2013: diakses tanggal 20 Februari 2015) yang di posting oleh Y Jamiah, kriteria persentase aktivitas sebagai berikut:

$$
\% \text { keaktifan }=\frac{\text { Skor } \text { yang diperoleh }}{\text { skor maksimum }} \boldsymbol{x 1 0 0}
$$

Kriteria Penilaian:

$75 \%<$ keaktifan $\leq 100 \%$ tergolong sangat aktif

$65 \%<$ keaktifan $\leq 74 \%$ tergolong aktif

$55 \%<$ keaktifan $\leq 64 \%$ tergolong cukup aktif

$0 \%<$ keaktifan $\leq 54 \%$ tergolong kurang aktif

\subsubsection{Tes Hasil Belajar}

Tes yang digunakan dalam penelitian disesuaikan dengan tujuan yang hendak dicapai. Adapun tes yang diberikan berbentuk Pilihan berganda sebanyak 29 soal dengan empat pilihan, dan dibagi dua, dimana 15 soal untuk siklus pertama dan 14 untuk siklus kedua.

Persentase Nilai $=\frac{\text { Nilai } y g \text { diperole } h \text { siswa }}{\text { jumla } h \text { nilai }} \times 100$

Kategori penilaian:

$$
\begin{array}{ll}
<70 & =\text { Tidak Kompoten } \\
70-79 & =\text { Cukup Kompoten } \\
80-89 & =\text { Kompoten } \\
90-100 & =\text { Sangat Kompoten }
\end{array}
$$

\section{Hasil Penelitian dan Pembahasan}

\subsection{Paparan Hasil Observasi Aktivitas Belajar} Siswa Siklus I

Hasil Observasi Aktivitas Siswa diperoleh dari kegiataan siswa dalam proses pembelajaran.

Aktivitas belajar siswa pada siklus I yang dinilai kepada 32 siswa, dimana siswa yang 
memperoleh katagori Kurang Aktif tidak ada, Cukup Aktif 14 orang, Aktif 10 orang dan katagori Sangat Aktif belum 8 orang. Sesuai dengan data tersebut maka aktivitas siswa dapat dikatakan sudah berhasil, tetapi mayoritas siswa masuk dalam kategori Cukup Aktif dan belum diketahui apakah aktivitas siswa masih akan meningkat, sehingga penelitaian dilanjutkan ke siklus II dengan menerapkan model pembelajaran Kontekstual dan memperhatikan kelemahan yang terjadi selama pelaksanaan siklus I.

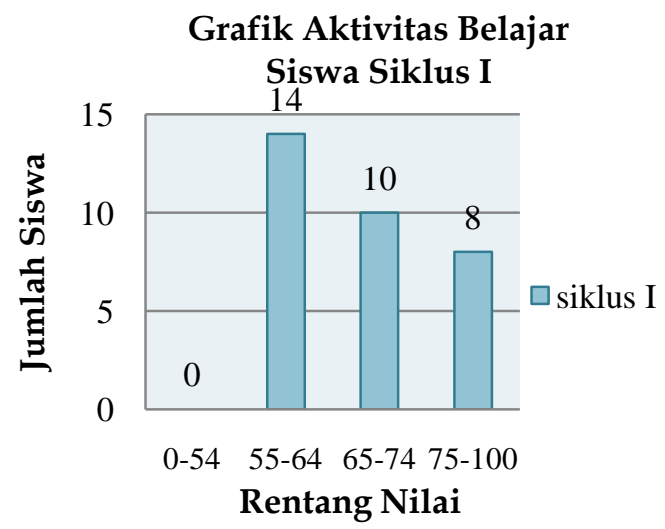

Gambar 1. Grafik Aktivitas Belajar Siswa Siklus I

Dari grafik diperoleh hasil belajar siswa diperoleh dari tes hasil belajar yang dikerjakan oleh siswa sesudah proses belajar mengajar dilaksanakan. Dari hasil belajar siswa yang diperoleh siswa pada waktu pelaksanaan tindakan selesai maka diketahui hasil belajar siswa dengan katagori tidak kompeten 15 siswa $(46,88 \%)$, kategori cukup kompeten 9 siswa $(28,13 \%)$, kategori kompeten 8 siswa $(25 \%)$, dan untuk katagori sangat kompeten belum ada.

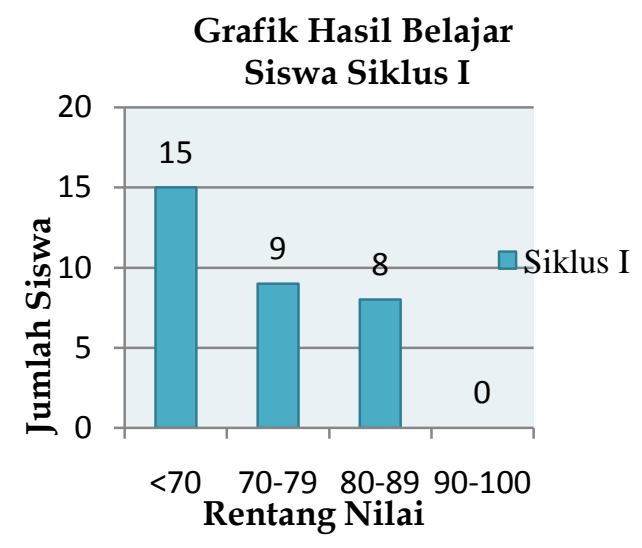

Gambar 2. Grafik Hasil Belajar Siswa Siklus I

\subsection{Paparan Hasil Observasi Aktivitas Belajar Siswa Siklus II}

Hasil Observasi Aktivitas Siswa diperoleh dari kegiataan siswa dalam proses pembelajaran pada siklus II, , dimana siswa yang memperoleh katagori Kurang Aktif tidak ada, Cukup Aktif tidak ada, Aktif 2 orang sedangkan untuk katagori Sangat Aktif 30 orang. Sesuai dengan data tersebut maka aktivitas siswa dapat sudah berhasil, dimana katagori Sangat Aktif telah mendominasi hasil penilaian dari empat katagori penilaian yang dibuat sebelumnya.

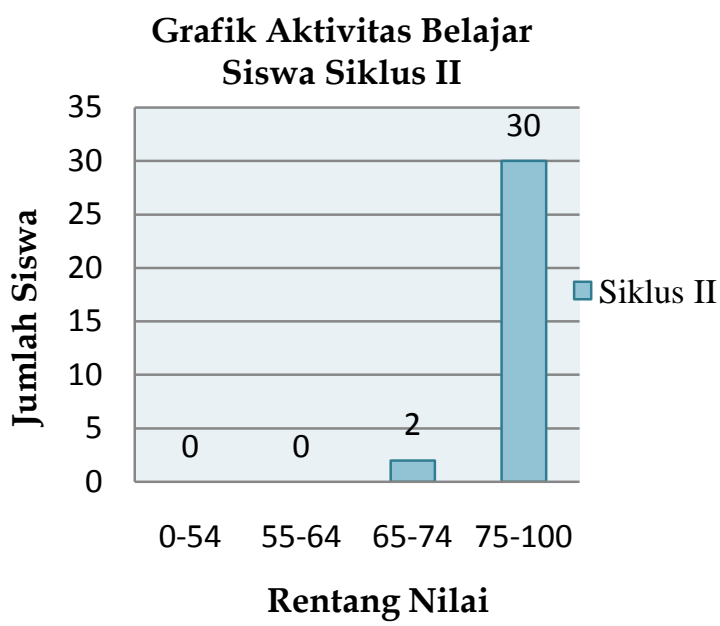

Gambar 3. Grafik Observasi aktivitas Belajar Siswa Siklus II

Dari hasil grafik belajar siswa yang diperoleh siswa pada waktu pelaksanaan tindakan selesai maka diketahui nilai hasil belajar siswa siklus II dengan kategori tidak kompeten tidak ada, kategori cukup kompeten 7 orang $(21,87 \%)$, kategori kompeten 15 orang $(46,87 \%)$ dan kategori sangat kompeten sebanyak 10 orang $(32,25 \%)$.

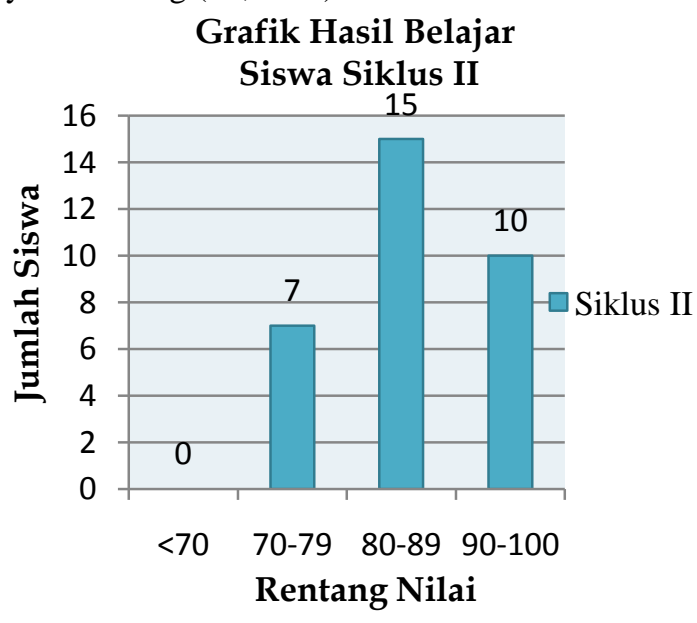

Gambar 4. Grafik Hasil Belajar Siswa Siklus II 


\section{Raden Ginting - Juanda Sianipar}

Berdasarkan hasil pengamatan selama proses belajar mengajar pada siklus II ini, dapat dilihat bahwa aktivitas dan hasil belajar siswa mengalami peningkatan, hampir semua siswa telah terbiasa dengan model pembelajaran kontekstual. Pada siklus II ini, siswa yang awalnya mayoritas pasif mulai berani untuk memberikan tanggapan, menjawab pertanyaan dan mengajukan pertanyaan. Selain itu, pada siklus ini, pemikiran siswa mulai berkembang dan dapat menghubungkan materi pelajaran dengan kehidupannya. Hal ini dapat terlihat dari tanggapan-tanggapan dan pertanyaan yang diajukan oleh siswa tersebut.

Hal ini membuktikan bahwa siklus selanjutnya tidak perlu dilakukan lagi. Oleh karena itu Penerapan pembelajaran Kontekstual dapat meningkatkan Aktivitas dan hasil belajar siswa kelas X Program Keahlian Teknik Gambar Bangunan pada mata pelajaran Ukur Tanah di SMK Negeri 1 Lubuk Pakam.

Dari hasil belajar pada siklus I dan siklus II dapat disimpulkan bahwa terjadi perbaikan pada setiap indikator, terutama pada Aktivitas dan hasil belajar siswa, sehingga penerapan model pembelajaran Kontekstual dapat meningkatkan Aktivitas dan hasil belajar siswa pada mata pelajaran Ukur Tanah. Berikut grafik peningkatan Aktivitas dan hasil belajar pada siklus I dan siklus II :

\section{Grafik Peningkatan Aktivitas Belajar Siswa}

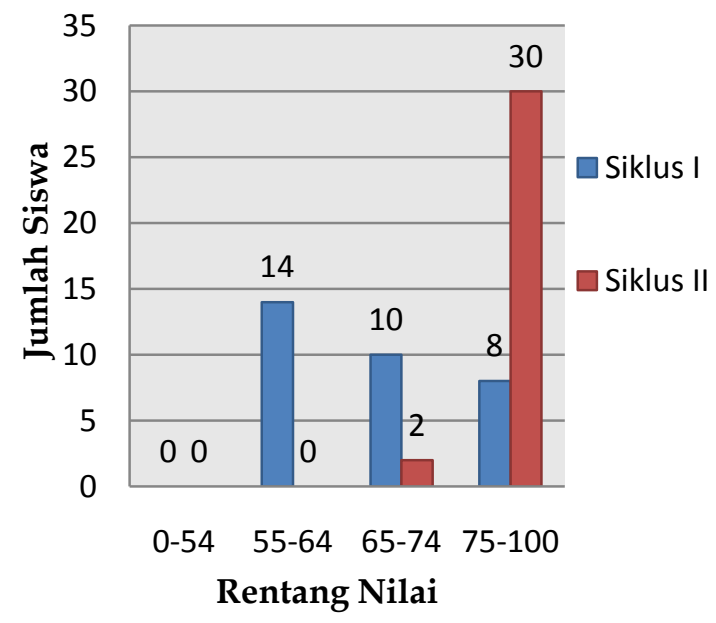

Gambar 5. Grafik Peningkatan Observasi Aktivitas Belajar Siklus I dan Siklus II

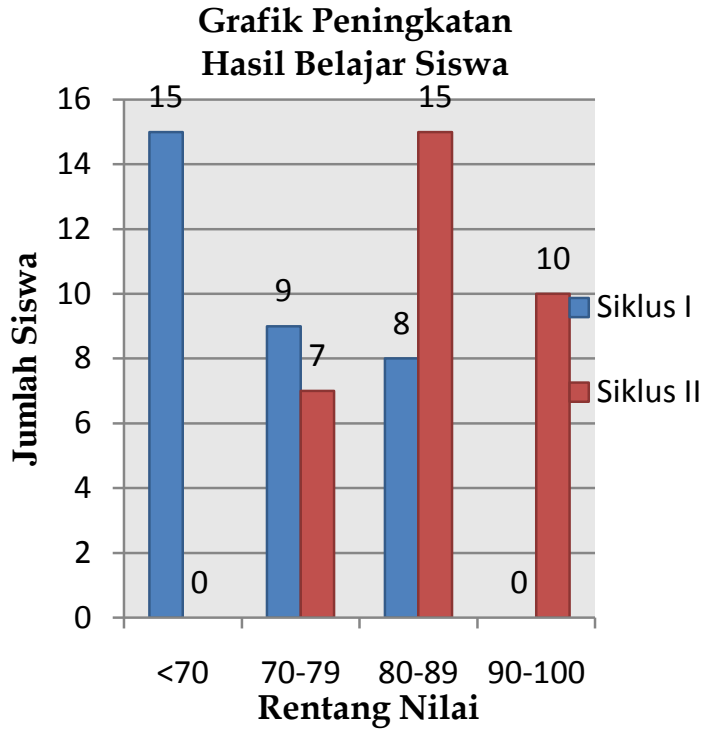

Gambar 6. Grafik Peningkatan Observasi Aktivitas Belajar Siklus I dan Siklus II

\section{Kesimpulan, Implikasi dan Saran}

\subsection{Kesimpulan}

Dari hasil analisis data dan pembahasan maka dapat diambil kesimpulandari penelitian, yaitu:

a. Penerapan Model Pembelajran Kontekstual dapat meningkatkan aktivitas siswa pada mata pelajaran Uur Tanah. Hal ini dapat dilihat dari perolehan nilai aktivitas siswa pada siklus I ke siklus II dengan penilaian kategori Kurang Aktif dari 0 orang menjadi 0, kategori Cukup Aktif dari 14 orang menjadi 0 orang, kategori Aktif dari 10 orang menjadi 2 orang dan kategori Sangat Aktif dari 8 menjadi 30 orang.

b. Penerapan Model Pembelajran Kontekstual dapat meningkatkan hasil belajar siswa pada mata pelajaran Uur Tanah. Hal ini dapat dilihat dari peningkatan nilai siswa dari siklus I ke siklus II dengan kategori Tidak Kompeten dari 15 orang menjadi 0, kategori Cukup Kompeten dari 9 orang menjadi 7 orang, kategori Kompeten dari 8 orang menjadi 15 orang dan kategori Sangat Kompeten dari 0 menjadi 10 orang.

\subsection{Implikasi}

Berdasarkan hasil penelitian dan kesimpulan penelitian diberikan implikasi sebagai berikut: 


\section{Penerapan Model Pembelajaran Kontekstual untuk Meningkatkan Aktivitas dan Hasil Belajar Ukur Tanah Siswa SMK Negeri 1 Lubuk Pakam}

a. Dengan diterimanya hipotesis pertama, maka perlu menjadi bahan pertimbangan bagi pihak sekolah maupun guru dalam menerapkan Model Pembelajaran Kontekstual untuk meningkatkan aktivitas siswa pada mata pelajaran Ukur Tanah.

b. Dengan diterimanya hipotesis kedua, maka perlu menjadi pertimbangan bagi pihak sekolah maupun guru dalam menerapkan Model Pembelajaran Kntekstual untuk meningkatkan hasil belajar siswa pada mata pelajaran Ukur Tanah.

\subsection{Saran}

Berdasarkan kesimpulan di atas, maka disarankan beberapa hal sebagai berikut:

a. Sebaiknya guru mengembangkan pemikiran siswa sebelum memulai suatu materi pelajaran.

b. Guru sebaiknya memberikan nilai tambahan kepada siswa yang mengajukan pertanyaan, menjawab pertanyaan, dan memberikan tanggapan selama proses belajar mengajar, karena dapat memotivasi siswa agar lebih aktif.

c. Bagi para guru, khususnya mata pelajaran Ukur Tanah, sebaiknya menerapkan model pembelajaran kontekstual untuk meningkatkan aktivitas dan hasil belajr siswa.

d. Untuk peneliti selanjutnya, dapat menggunakan judul yang sama namun untuk waktu yang lebih lama dengan sumber yang lebih luas, agar dapat dijadikan suatu studi perbandingan bagi guru dalam meningkatkan kualitas pendidikan khususnya pada mata pelajaran Ukur Tanah.

\section{Daftar Pustaka}

Arikunto, Suharsimi. 2009. Dasar-dasar Evaluasi Pendidikan. Jakarta: Bumi Aksara.

Arikunto, Suharsimi. 2010. Prosedur Penelitian suatu Pendekatan Praktik. Jakarta: Rineka Cipta.

Arikunto, Suharsimi, dkk. 2008. Penelitian Tindakan Kelas. Jakarta: Bumi Aksara.

Azwaruddin. 2008. Pengertian Ilmu Ukur Tanah (Online) (http://azwaruddin.blogspot.com/2008 102/pengertian-ilmu-ikur-tanah.html, diakses tanggal 10 Agustus 2014)
Hamalik, O. 2009. Proses Belajar Mengajar. Jakarta : Bumi Aksara.

Iskandar. 2012. Metode Penelitian Pendidikan dan Sosial. Jakarta: Gaung Press.

Jamiah, Y. 2013. Peningkatan Aktivitas Belajar Siswa Kelas VII SMP pada Bilangan Pecahan dengan Teori Bruner (Online). (http:// download.portalgaruda.org/arti cle.php?article $=130015 \& \mathrm{val}=2338 \&$ title $=$ PENINGKATAN\%20AKTIVITAS\%20BE LAJAR \% 20SISWA \% 20KELAS $\% 20 \mathrm{VII} \% 20$ SMP\%20PADA\%20BILANGAN\%20PEC AHAN\%20DENGAN\%20TEORI\%20BRU NER, diakses 20 Februari 2015)

Muda, Iskandar. 2008. Teknik Survey dan Pemetaan Jilid 1 untuk Sekolah Menengah Kejuruan. Jakarta: Direktoret Pembinaan Sekolah Menengah Kejuruan.

Nurhadi. 2003. Pendekatan Kontekstual. Jakarta: Departemen Pendidikan Nasional.

Riyanto, Yatim. 2009. Paradigma Baru Pembelajaran. Jakarta : Kencana Prenada Media Group.

Rusman. 2012. Model-model Pembelajaran Mengembangkan Profesionalisme Guru. Depok: Rajagrafindo Perkasa.

Saleh, Salmani. 2011. Ilmu Ukur Tanah (Online). (http:// salmanisaleh.files.wordpress.com/2011/03/99-pengukuranpolygon2.pdf, diakses tanggal 10 Agustus 2014).

Sanjaya, Wina. 2006. Strategi Pembelajaran Berorientasi Standar Proses Pendidikan. Jakarta : Kharisma Putra Utama.

Sardiman. 2008. Interaksi dan Motivasi Belajar Mengajar. Jakarta : Rajawali.

Setiawan, Deny. 2013. Metode Penelitian Teknik Penulisan Skripsi. Medan: UNIMED

Slameto. 2003. Belajar dan Faktor-faktor yang Mempengaruhinya. Jakarta : Rineka Cipta.

Sudjana, N. 2009. Penilaian Hasil Proses Belajar Mengajar. Bandung: Remaja Rosdakarya.

Trianto. 2007. Model-Model Pembelajaran Inovatif Berorientasi Konstruktifistik. Jakarta: Prestasi Pustaka.

Usman Ardhi, Fauzi. 2012. Aktivitas Belajar (Online),(http://eprints.uny.ac.id/8442 $\angle 3 /$ bab\%202.pdf, diakses 16 Januari 2014) 